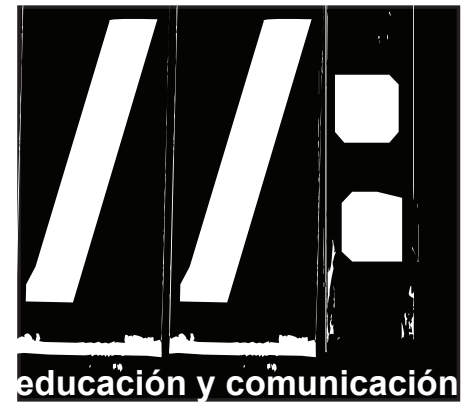

\title{
VIDA UNIVERSITARIA Y LEYENDAS DE LA BIBLIOTECA. IV Certamen Literario de Narrativa breve. Bihlioteca UCA
}

\section{Autoras: Varios.}

Añ̃o: 2016

Editorial: Universidad de Cádiz

Localidad: Gádiz

13: 141-142 Nov. 2016

José Manuel Vargas Sánchez.

Universidad de Cádiz (España)

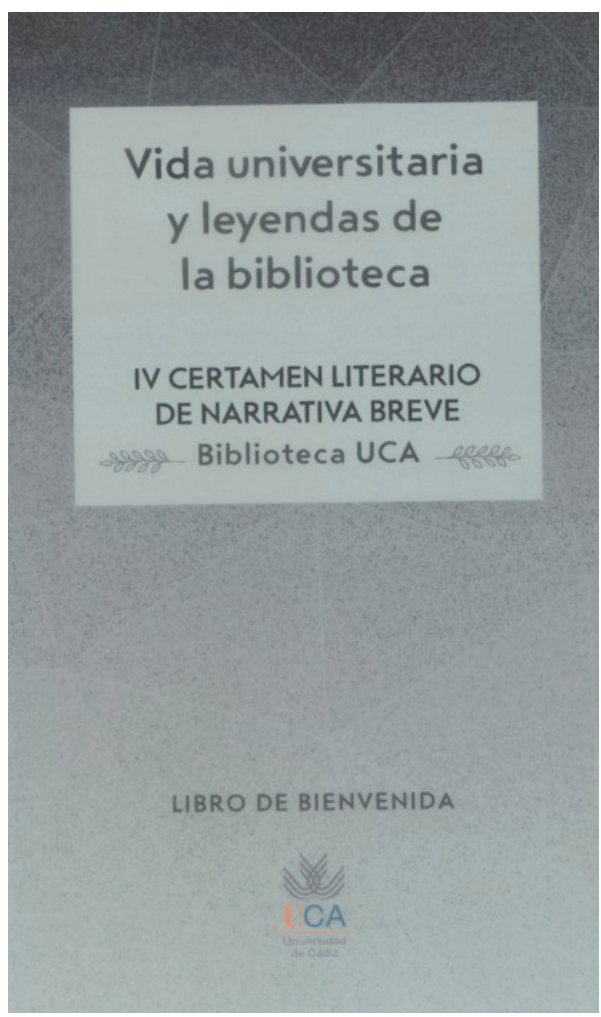




\section{II: Derechos humanos educación y comunicación}

E conmemoración del inicio del curso académico 2016-2017, el Vicerrectorado de Responsabilidad Social, Extensión Cultural y Servicios, en coordinación con el Grupo de Responsabilidad Social del Área de Biblioteca y Archivo y con la colaboración del Consejo social y del Servicio de Publicaciones, ha convocado el IV Certamen Literario de Narrativa Breve "Biblioteca UCA". Un año más, el resultado de esta generosa iniciativa es la publicación de cinco relatos, cuyo eje inspirador lo constituye el mundo universitario, agrupados bajo el título Vida universitaria $y$ leyendas de biblioteca.

El libro se inicia, a modo de prólogo, con unas cálidas palabras de bienvenida del Rector de la Universidad de Cádiz, Eduardo González Mazo, seguidas de la salutación de la Presidenta del Consejo Social, Ana Alonso Lorente.

Si bien es cierto que la escritura implica un viaje hacia el interior, no resulta menos relevante la necesidad de conocer el sentir y el pensar de los demás para así entroncar con los intereses colectivos. Por tal razón, la capacidad de inventiva de los cinco candidatos premiados supone la piedra de toque en esta labor de comunicación, de saber hacer cosas con las palabras. En Con otros ojos, la misma luz, de David Hernández Ortega, el autor nos hace partícipe del balance personal que realiza a lo largo del relato durante los años transcurridos en la universidad. Un recorrido a través de los recovecos de la memoria por momentos que marcan un antes y un después en su existencia.

Sandra Chinesta Sevilla nos sorprende con El trozo de papel, donde el hallazgo de un libro la transporta en un viaje por el tiempo a su época universitaria en un inesperado encuentro con su yo, con tintes oníricos, al más puro estilo borgiano.
En el tercer relato, El lugar donde a nadie le importe nada, de Juan Miguel Caballero Sánchez, la biblioteca cobra gran protagonismo, pues será el germen de una historia de amor donde el protagonista experimentará inesperadamente un trasvase a nivel emocional.

Envuelto en un ambiente apocalíptico y con la universidad como telón de fondo, Virus UCA, de Pedro Delgado Pérez, juega con el lector entrelazando episodios paralelos de distintas historias que convergen en un testimonio esclarecedor del protagonista, dotando así al relato de ingenio y comicidad.

Finalmente, Sergio Díaz Valenzuela tantea con elegancia la vena sensible del lector con Geelah, un relato tan realista como desgarrador donde la injusticia social supondrá el punto de inflexión que iluminará a la protagonista en sus intereses universitarios y profesionales.

Con este pequeño ejemplar como obsequio de bienvenida, se pretende fomentar e impulsar la escritura, tan necesaria para los más ávidos lectores como gratificante para aquellos que se atreven a indagar en su imaginario creativo, aportando así la genialidad al comienzo de un nuevo curso, a la apertura de una nueva etapa vital, que deseamos próspera y enriquecedora para todos aquellos que entran a formar parte de nuestro mundo universitario. Disfruten de la lectura, pues nunca es tarde para empezar a leer. 